\title{
Synthesis and characterization of thermosensitive hydrogels and the investigation of modified release of ibuprofen
}

\author{
Snežana S. Ilić-Stojanović ${ }^{1}$, Ljubiša B. Nikolic ${ }^{1}$, Vesna D. Nikolić ${ }^{1}$, Jela R. Milić ${ }^{2}$, Jakov Stamenković ${ }^{1}$, \\ Goran M. Nikolić ${ }^{3}$, Slobodan D. Petrović ${ }^{4}$ \\ ${ }^{1}$ University of Niš, Faculty of Technology, Leskovac, Serbia \\ ${ }^{2}$ University of Belgrade, Faculty of Pharmacy, Belgrade, Serbia \\ ${ }^{3}$ University of Niš, Faculty of Medicine, Niš, Serbia \\ ${ }^{4}$ University of Belgrade, Faculty of Technology and Metallurgy, Belgrade, Serbia
}

\begin{abstract}
The method of the synthesis of poly( $N$-isopropylacrylamide-co-2-hydroxypropyl methacrylate) hydrogels obtained by radical polymerization is described. Their characterization was carried out by the determination of the quantity of residual monomers and by investigating their structure using FTIR. Three glass transitions were detected by DSC method. The porous surfaces of hydrogels with incorporated ibuprofen were shown in SEM micrographs. The swelling ratio of hydrogels decreased with the temperature increase and the swelling transport mechanism changed from non-Fickian to Fickian. Ibuprofen was incorporated in the hydrogel as a drug carrier and the released quantity depending on the temperature was monitored by HPLC. The hydrogel with the lower cross-linker content had the highest swelling degree $(\alpha=34.72)$ at $10^{\circ} \mathrm{C}$ and released the largest amount of ibuprofen $\left(64.21 \mathrm{mg} / \mathrm{g}_{\text {xerogel }}\right)$ at $40{ }^{\circ} \mathrm{C}$.
\end{abstract}

Keywords: $\mathrm{N}$-isopropylacrylamide, copolymer hydrogel, thermal properties, swelling, ibuprofen.

\section{Polymers}

SCIENTIFIC PAPER

UDC 678-13:66.095.26:547.057

Hem. Ind. 67 (6) 901-912 (2013)

doi: 10.2298/HEMIND130119038I

Available online at the Journal website: http://www.ache.org.rs/HI/

Hydrogels are polymer materials that have the ability to swell in water and to absorb great quantities of water or other physiological fluids within their structures, whereby their structure remains unchanged. Due to large water content, soft and elastic consistency, hydrogels, more than any other class of synthesized biomaterials, resemble living tissue [1]. They have the ability to respond to different environmental changes and show a dramatic change in properties such as the change of swelling degree; because of this they are named "smart" or "intelligent" gels.

In the last twenty years, hydrogels, and especially poly( $N$-isopropylacrylamide), pNIPAM, have drawn great attention of researchers with respect to their application in medicine and pharmaceuticals [2]. Poly( $N$-isopropylacrylamide) is a biocompatible and nonbiodegradable temperature-responsive hydrogel which has both hydrophilic and hydrophobic groups. The ability of hydrogels to absorb and release molecules of different size has enabled their use as carriers in the systems for the controlled release of drugs [3]. $\mathrm{N}$-Isopropylacrylamide (NIPAM) was first synthesized by Coover and Shearer in 1953 [4]. The effects of external stimuli on some polymers were investigated in the

Correspondence: S. Ilić-Stojanović, University of Niš, Faculty of Technology, Bulevar oslobođenja 124, 16000 Leskovac, Serbia.

E-mail: ilic.s.snezana@gmail.com

Paper received: 19 January, 2013

Paper accepted: 19 April, 2013 1960's by Heskins and Guillet [5]. They found that under standard conditions, the lower critical solution temperature (LCST) at which pNIPAM passed through the phase transition was $32{ }^{\circ} \mathrm{C}$. At temperatures below LCST, it exhibits a hydrophilic nature because the interaction of polymer chains with water molecules is dominant and hydration of hydrophobic groups of the polymer chain occurs, hydrogen bonds are formed and the gel swells. The conformation changes are primarily the result of releasing water molecules from the polymer structure [6].

To achieve the required temperature and $\mathrm{pH}$ sensitivity of a hydrogel during the synthesis, it is common to copolymerize the thermo-sensitive component, most often NIPAM, with a certain quantity of anionic monomer-acrylic, methacrylic, maleic, or itaconic acid [7-11]. By adjusting the composition of copolymer it is possible to bring the LCST value closer to physiological temperature $\left(36-38^{\circ} \mathrm{C}\right)$, which is especially important for the controlled release of drugs [12-13]. There are many published works which report the use of thermal analysis, study the phase transition of pNIPAM gels and measure LCST by using differential scanning calorimetry (DSC) [14-17]. The glass transition temperature $(\mathrm{Tg})$ of pNIPAM and copolymers of poly( $N$-isopropylacrylamide)-co-acrylamide was determined by using DSC [18]. At higher temperatures, the structure of the gel wrapper is controlled by introducing hydrophilic acrylamide as the functional temperature-sensitive intelli- 
gent system with the controlled drug release rate [19-21]. NIPAM gel is used for the design of the positive thermosensitive pulsing drug release system so that the drug release is triggered by the temperature increase and stopped by the temperature decrease [22-25].

Hydrophilic 2-hydroxypropyl methacrylate (HPMet) is a convenient biocompatible material with living tissues and satisfactory tolerance by cells [26]. It can copolymerize with other monomers to produce copolymers with a hydroxyl group at the chain end. It has the ability to preserve living tissues and antigens against various enzymes and reagents, and presents an excellent choice for various immunocytochemical procedures [27]. The controlled polymerization of two industrially relevant hydroxy-functional monomers, glycerol monomethacrylate and HPMet was investigated [28]. The isolation of lignin from the water mixture by using copolymer of NIPAM and HPMet was studied [14]. The synthesis of hydrogels based on NIPAM with HPMet obtained by gamma irradiation, their characterization and the investigation of caffeine release properties was investigated [29]. Unlike the corresponding copolymers, thermosensitive hydrogels based on NIPAM with HPMet have not been studied to great extent.

The aims of this paper were: the synthesis of poly( $N$-isopropylacrylamide-co-2-hydroxypropyl methacrylate) hydrogels, p(NIPAM-co-HPMet) by radical polymerization, their characterization and investigation of their application as a drug carrier. The structures of the obtained copolymers were characterized using FTIR, SEM and DSC techniques and by analyzing the residual monomer content and swelling behavior. From the standpoint of safety ibuprofen, 2-(4-isobutylphenyl) propionic acid was selected as a model drug. Ever since clinical tests in 1966 proved the activity of ibuprofen in the treatment of rheumatoid arthritis, and the first commercialization in 1969, ibuprofen has become one of the most important non-steroidal anti-inflammatory drugs (NSAID) [30,31]. The influence of monomer and cross-linker molar ratio on their swelling behavior was already published [32]. The presented results are one part of an extensive research concerning the possibility of application of $p$ (NIPAM-co-HPMet) hydrogels as potential carriers for modified delivery of NSAID [33].

\section{EXPERIMENTAL}

\section{Reagents}

$\mathrm{N}$-Isopropylacrylamide (NIPAM) 99\%, 2-hydroxypropyl methacrylate (HPMet) $96.5 \%$ and 2,2'-azobis(2methylpropionitrile) (AZDN) $98 \%$ by Acros Organics, New Jersey, US; ethylene glycol dimethacylate (EGDM) $97 \%$ by Fluka Chemical Corp., $\mathrm{CH}$; acetone by Centrohem, Belgrade, RS; methanol by Unichem, Belgrade, RS; ibuprofen $98 \%$ by Sigma-Aldrich Co., US.

\section{Synthesis of $p$ (NIPAM-co-HPMet) hydrogel}

Cross-linked copolymers of NIPAM with 5 mol\% of HPMet, in reference to the amount of NIPAM monomer, were obtained by radical polymerization using EGDM as a cross-linker and AZDN as the initiator in acetone as the solvent. EGDM concentration in the reaction mixture varied: $0.5,1,1.5,2$ and $3 \mathrm{~mol} \% \mathrm{com}$ pared to the total comonomer mass. After homogenization and the monomer dilution, the reaction mixture was injected into glass tubes which were then fused, and subjected to polymerization under the temperature regime: $70{ }^{\circ} \mathrm{C} 2 \mathrm{~h}, 80^{\circ} \mathrm{C} 1 \mathrm{~h}$, and $85^{\circ} \mathrm{C} 0.5 \mathrm{~h}$ to activate the initiator and the polymerization process, and for the full utilization of the initiator. After cooling, the obtained gels were separated from the glass tubes. Gels were extracted by methanol to remove all nonreacted water-insoluble compounds, monomers and oligomers. Methanol was changed daily for three days. Then, they were submerged into methanol/distilled water solutions in $75 / 25,50 / 50,25 / 75$ and $0 / 100 \%$ ratios and kept for a day in the order to effect flushing of methanol from the hydrogel. The extracts were analyzed by HPLC method to determine the amount of a residual monomer. Swollen gels were dried to constant mass at 20 to $40{ }^{\circ} \mathrm{C}$ to pass into the xerogel stage for further testing.

\section{Characterization of p(NIPAM-co-HPMet) hydrogel}

\section{Fourier transform infrared spectroscopy (FTIR)}

Samples of $1 \mathrm{mg}$ of synthesized copolymers were pressed into a pellet with $150 \mathrm{mg}$ of $\mathrm{KBr}$ of spectrophotometric purity and FTIR spectra were recorded on a BOMEM MB-100 (Hartmann \& Braun, Canada) in the wavelength range of $4000-400 \mathrm{~cm}^{-1}$.

\section{Scanning electron microscopy (SEM)}

Samples of swollen p(NIPAM-co-HPMet) hydrogel, one pure and one with loaded ibuprofen, were first lyophylised for SEM microscopy and then metalized by gold-palladium alloy (15/85) and then recorded on a JEOL scanning microscope JSM-5300.

\section{Differential scanning calorimetry (DSC)}

Thermal properties of samples were investigated by differential scanning calorimetry (DSC) by using a DSC Q100 (TA instruments). The samples were heated at ramping rate of $10{ }^{\circ} \mathrm{C} \mathrm{min}^{-1}$, with the gas flow (nitrogen) $50 \mathrm{~cm}^{3} \mathrm{~min}^{-1}$ and the weight of the tested samples was about $3 \mathrm{mg}$. Standard calibration was performed by using indium, the melting temperature of which was $157{ }^{\circ} \mathrm{C}$. The sensitivity of the instrument was $10 \mathrm{mV}$ $\mathrm{cm}^{-1}$.

\section{Residual monomers analysis}

The solutions obtained by the extraction of polymerized gels were analyzed by HPLC method on the 
device: Agilent 1100 Series, column: ZORBAX XDB-C18 $250 \mathrm{~mm} \times 4.6 \mathrm{~mm}, 5 \mu \mathrm{m}$, eluent: methanol, flow rate: 1 $\mathrm{cm}^{3} \mathrm{~min}^{-1}$, injected sample volume: $10 \mu \mathrm{l}$, temperature: $25{ }^{\circ} \mathrm{C}$, detector: DAD $1 \mathrm{~A}$, detection wavelength: 220 $\mathrm{nm}$.

\section{Swelling behavior}

Xerogels were immersed in distilled water and swelling was monitored gravimetrically at temperatures from 10 to $50{ }^{\circ} \mathrm{C}$. The swelling ratio, $\alpha$, was calculated as:

$$
\alpha=\frac{m-m_{0}}{m_{0}}
$$

where $m_{0}$ is the mass of xerogel and $m$ is the mass of swollen gel at the time $t$.

\section{Loading and release of ibuprofen studies}

In order to investigate the possibilities of the application of synthesized hydrogels as carriers for the modified release, ibuprofen was used as the model drug. The xerogel was swollen in the ibuprofen solution in methanol/distilled water mixture (80/20), $40 \mathrm{mg} \mathrm{cm}^{-3}$ for $48 \mathrm{~h}$.

The swollen gel was soaked with $7 \mathrm{~cm}^{3}$ of distilled water and the amount of the released ibuprofen was monitored for $24 \mathrm{~h}$ at the temperatures of 20 and 40 ${ }^{\circ} \mathrm{C}$. The content and amount of the released ibuprofen was performed by HPLC an Agilent 1100 Series device, under the following conditions: detector: DAD 1200; detection wavelength: $225 \mathrm{~nm}$, column: Zorbax XDBC18, $250 \mathrm{~mm} \times 4.6 \mathrm{~mm}, 5 \mu \mathrm{m}$, eluent: methanol/distilled water, 80/20; eluent flow: $1 \mathrm{~cm}^{3} \mathrm{~min}^{-1}$; injected sample volume: $20 \mu \mathrm{l}$, temperature: $25^{\circ} \mathrm{C}$.

\section{RESULTS AND DISCUSSION}

\section{Synthesis of p(NIPAM-co-HPMet) hydrogel}

The synthesis of $p$ (NIPAM-co-HPMet) hydrogel was performed with $0.5,1,2$ and 3 mol\% of EGDM. The obtained product with cross-linker content below 1 mol\% of EGDM remained in solution state after polymerization without required hydrogel consistency, and as such it was not used for further analysis.

\section{Characterization of p(NIPAM-co-HPMet) hydrogel \\ Fourier transform infrared spectroscopy (FTIR)}

The nature of bonding and the structure of obtained hydrogels were characterized by FTIR. Figure 1 shows FTIR spectra of NIPAM and HPMet monomers and EGDM cross-linker.

In FTIR spectra of NIPAM the following bands were observed: $v_{s}\left(\mathrm{CH}_{3}\right)$ at $2875 \mathrm{~cm}^{-1}, v_{\text {as }}\left(\mathrm{CH}_{3}\right)$ at $2970 \mathrm{~cm}^{-1}$, $v_{\text {as }}\left(\mathrm{CH}_{2}\right)$ at $2933 \mathrm{~cm}^{-1}, v_{\text {as }}(\mathrm{CH})$ from the vinyl group at $3072 \mathrm{~cm}^{-1}$ where the typical absorption amounts are between $3000-3100 \mathrm{~cm}^{-1}$. The valence absorption of $\mathrm{N}-\mathrm{H}$ bond from the amide structure was observed at $3284 \mathrm{~cm}^{-1}$, while the amide band I was observed at $1658 \mathrm{~cm}^{-1}$. The band at $1622 \mathrm{~cm}^{-1}$ originated from the valence vibrations of the $\mathrm{C}=\mathrm{C}$ double bond.

The FTIR spectrum of HPMet monomer showed a wide band originating from the valence vibration of the $\mathrm{O}-\mathrm{H}$ group and was present between $3100-3600 \mathrm{~cm}^{-1}$ with a peak at $3450 \mathrm{~cm}^{-1}$. Symmetrical and asymmetrical bands from $\mathrm{C}-\mathrm{H}$ vibrations were also present: $v_{\mathrm{s}}\left(\mathrm{CH}_{3}\right)$ at $2894 \mathrm{~cm}^{-1}$ and $v_{\text {as }}\left(\mathrm{CH}_{3}\right)$ at $2980 \mathrm{~cm}^{-1}$. Valence vibrations of the $\mathrm{C}=\mathrm{C}$ double bond were observed at $1638 \mathrm{~cm}^{-1}$.

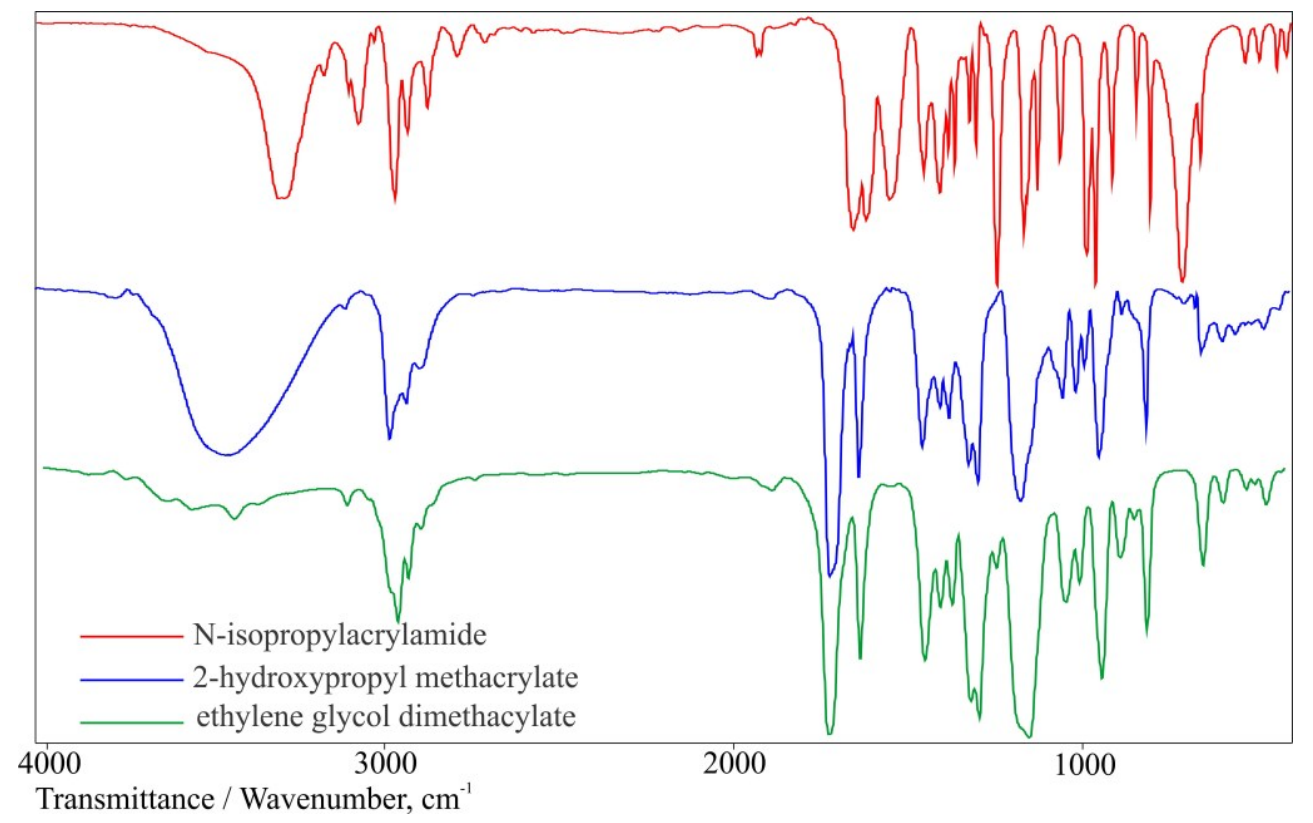

Figure 1. FTIR Spectra of NIPAM, HPMet and EGDM. 
In the FTIR spectrum of EGDM a band from the valence vibrations of the $\mathrm{C}=\mathrm{O}$ ester group were present, conjugated with double $\mathrm{C}=\mathrm{C}$ bond, with a peak at $1725 \mathrm{~cm}^{-1}$. There are peaks originating from valence vibrations of $\mathrm{C}-\mathrm{O}$ bond, reflected by wide peaks at about 1150 to $1180 \mathrm{~cm}^{-1}$. The peak at $1636 \mathrm{~cm}^{-1}$ originated from the absorption of the double bond. Also, the bands: $v_{s}\left(\mathrm{CH}_{3}\right)$ at $2894 \mathrm{~cm}^{-1}, v_{\text {as }}\left(\mathrm{CH}_{3}\right)$ at $2960 \mathrm{~cm}^{-1}$, $v_{\text {as }}\left(\mathrm{CH}_{2}\right)$ at $2930 \mathrm{~cm}^{-1}, v_{\text {as }}(\mathrm{CH})$ from the vinyl group at $3105 \mathrm{~cm}^{-1}$ were observed.

Figure 2 shows FTIR spectra of synthesized p(NIPAM-co-HPMet) xerogels with: $1,1.5,2$ and 3 mol\% of EGDM. Since the hydrogel synthesis was carried out by the initiation using radicals formed by decomposition of AZDN, there appeared to be no absorption in gel FTIR spectra that could originate from the double $\mathrm{C}=\mathrm{C}$ bond. $\mathrm{N}-\mathrm{H}$ and $\mathrm{O}-\mathrm{H}$ groups in the polymer chains were observed as lateral groups. In FTIR spectra, wide bands in the range from 3100 to $3600 \mathrm{~cm}^{-1}$ were observed, with clearly indicated peaks at about 3282 $\mathrm{cm}^{-1}$ and $3431 \mathrm{~cm}^{-1}$, originating from valence vibrations of $\mathrm{N}-\mathrm{H}$ and $\mathrm{O}-\mathrm{H}$ groups, respectively. Also, there was a band originating from amide band I from $\mathrm{C}=\mathrm{O}$ amide at $1648 \mathrm{~cm}^{-1}, \mathrm{C}=0$ valence from ester at $1716 \mathrm{~cm}^{-1}$, as well as the bands originating from valence vibrations of $\mathrm{C}-\mathrm{H}$ bonds of methyl and methylene groups in the range $2800-3000 \mathrm{~cm}^{-1}$. FTIR spectra of $\mathrm{p}$ (NIPAM-co-HPMet) with different molar ratio of EGDM crosslinker had a similar aspect since the concentration of EGDM was too low to be noticed in FTIR spectra. On the other hand, the monomer ratio in the copolymer was identical.

\section{Scanning electron microscopy (SEM)}

SEM was used to investigate the morphology of obtained hydrogel. In Figure 3a, the SEM micrograph of hydrogel of $p$ (NIPAM-co-HPMet) is given, showing the structure of hydrogel with the characteristic porous surface. The hydrogel morphology has a structure with spherical and ellipsoidal surfaces that probably facilitate and accelerate the absorption of water into the gel. All hydrogel samples with different cross-linker ratios show a similar surface structure. Figure $3 \mathrm{~b}$ presents the surface structure of hydrogel with the loaded particle of ibuprofen.

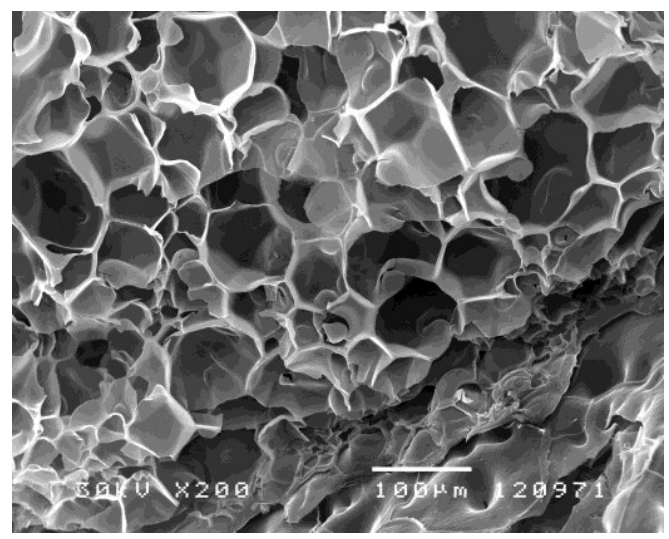

(a)

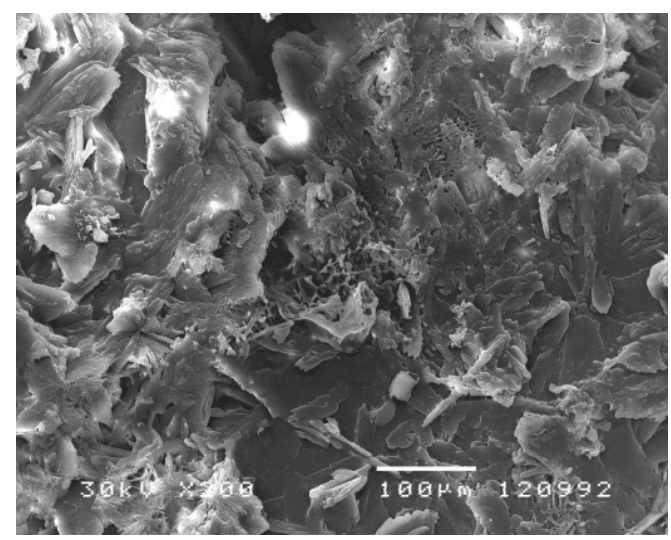

(b)

Figure 3. SEM Micrographs of $p$ (NIPAM-co-HPMet): a) pure and b) with loaded ibuprofen.

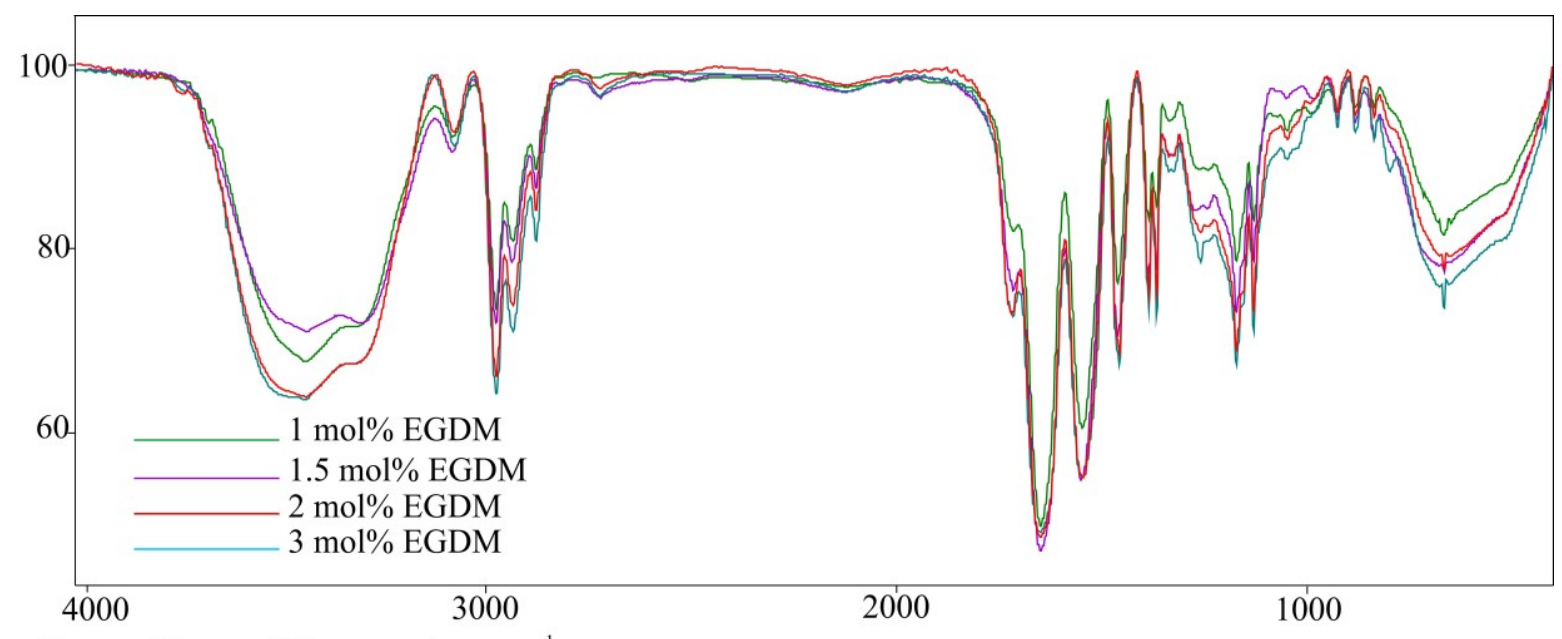

Transmittance / Wavenumber, $\mathrm{cm}^{-1}$

Figure 2. FTIR Spectra of p(NIPAM-co-HPMet) xerogels with 1, 1.5, 2 and 3 mol\% of EGDM. 


\section{Differential scanning calorimetry (DSC)}

The glass transition temperature of copolymerized xerogels was investigated. DSC thermograms obtained for p(NIPAM-Co-HPMet) copolymers with 1, 2 and 3 mol\% of EGDM in the themperature range $50-100{ }^{\circ} \mathrm{C}$ and $100-150{ }^{\circ} \mathrm{C}$ are showed in Figure $4 \mathrm{a}$ and $\mathrm{b}$, respectively, as well as Table 1 . As it can be seen, $\mathrm{p}$ (NIPAM-co-HPMet) has three glass transition temperatures determined with the endothermic peaks of weak intensity. The result analysis showed that thermal properties of $\mathrm{p}$ (NIPAM-co-HPMet) xerogels do not show a sharp phase transition to glassy state. The occurrence of 3 glass transitions may be due to struc- tural irregularities of polymer networks with different crosslinking ratio and the presence of retained traces of unreacted monomers in the polymer network. According to available literature data, the pNIPAM xerogel has two glass transition temperatures $T_{\mathrm{g}}$ at 85 and $135{ }^{\circ} \mathrm{C}$ [18,34-36], while pHPMet has a $T_{\mathrm{g}}$ at $95{ }^{\circ} \mathrm{C}$ [37]. The first and the third glass transition temperature $\left(T_{\mathrm{g} 1}\right.$ and $T_{\mathrm{g} 3}$ ) may be due to pNIPAM, and the second one $T_{\mathrm{g} 2}$, in the temperature range $75-85^{\circ} \mathrm{C}$ is due to pHPMet.

The values of $T_{\mathrm{g} 1}$ and $T_{\mathrm{g} 2}$ indicated the increasing trend when the cross-linker content increased, as it can be seen in Table 1. This was obvious because the increase in the crosslinker content in p(NIPAM-coHPMet) xerogels resulted in higher dense networks

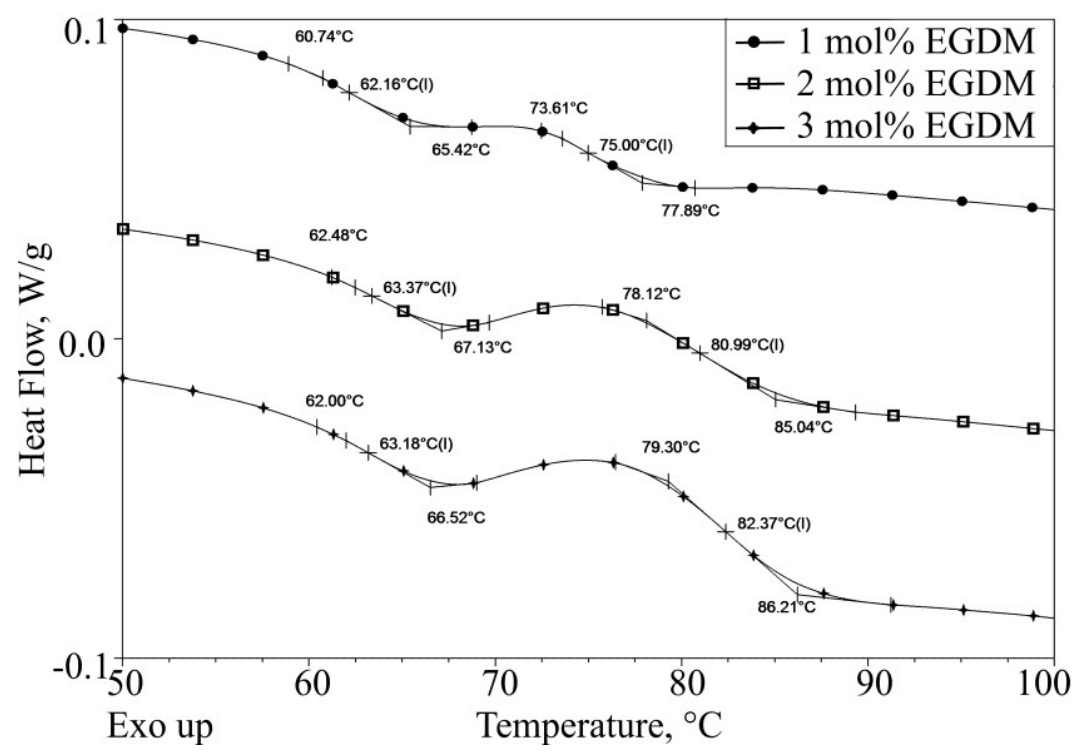

(a)

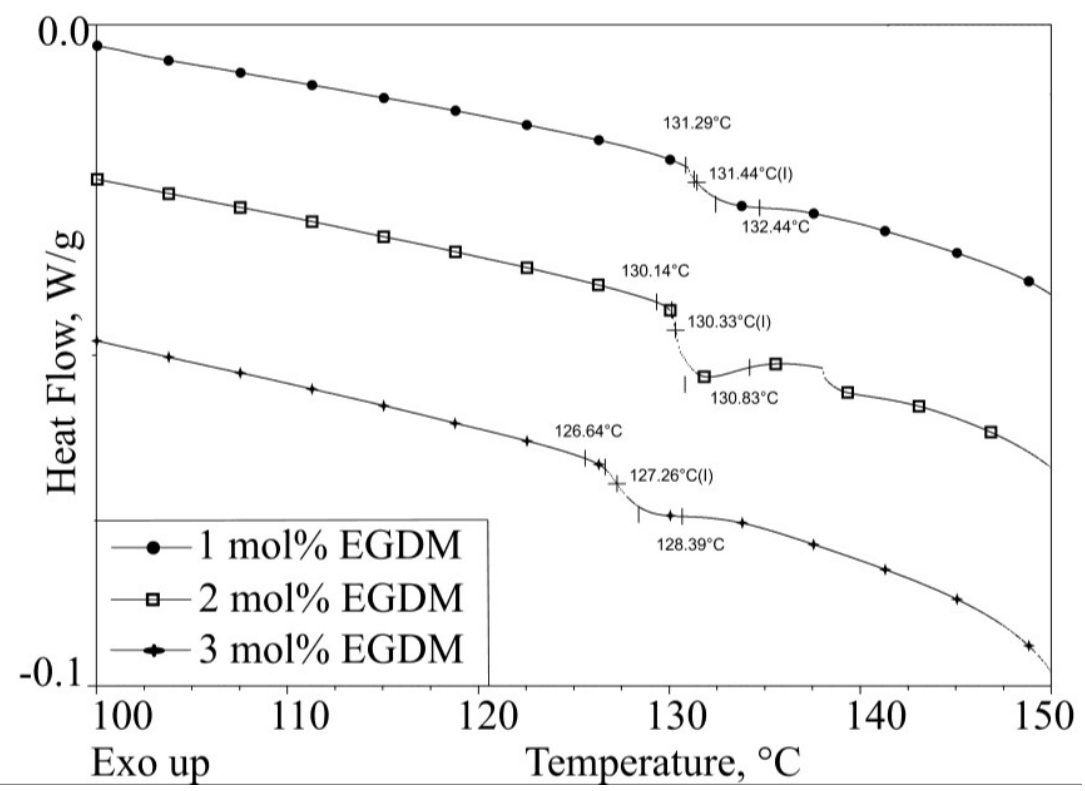

(b)

Figure 4. DSC Thermograms of $p$ (NIPAM-co-HPMet) in temperature range: a) $50-100^{\circ} \mathrm{C}$ and b) $100-150{ }^{\circ} \mathrm{C}$. 
that lead to higher $T_{\mathrm{g}}$ values. It can be noticed that the values of $T_{\mathrm{g} 3}$ of copolymers $\mathrm{p}$ (NIPAM-co-HPMet) were decreased in comparison to pNIPAM homopolymer, when adding a certain amount of HPMet monomer. The $\mathrm{p}$ (NIPAM-co-HPMet) copolymers reached the third phase transition to glassy state at lower temperature values, proportionally to mole ratio of the cross-linker. The decrease of cross-linking ratio in copolymer leads to less crystalline structure, because the crystalline domains which occur in pure pNIPAM disappear. All xerogels were synthesized under the same conditions and with the same HPMet monomer content (5 mol\%) and the only difference was the cross-linker content. It can be seen that small differences in $T_{\mathrm{g}}$ were caused by differences in the density of the polymer network, which is directly related to polymer-polymer interactions.

Table 1. Glass transition temperatures of p(NIPAM-co-HPMet) xerogels

\begin{tabular}{lccc}
\hline EGDM content, mol\% & $T_{\mathrm{g} 1} /{ }^{\circ} \mathrm{C}$ & $T_{\mathrm{g} 2} /{ }^{\circ} \mathrm{C}$ & $T_{\mathrm{g} 3} /{ }^{\circ} \mathrm{C}$ \\
\hline 1 & 62.16 & 75.00 & 131.44 \\
2 & 63.37 & 80.99 & 130.33 \\
3 & 63.18 & 80.37 & 127.26 \\
\hline
\end{tabular}

\section{Residual monomer analysis}

HPLC Chromatographs of NIPAM and HPMet hydrogels monomers were made on DAD detector. The monomer concentration was determined based on the calibration curve.

The dependence of the peak area on NIPAM concentration was linear for concentration range of $1 \mathrm{mg}$ $\mathrm{cm}^{-3}$, for which the following equation applies:

$C=\frac{A-113}{26652.8}$ where $A$ is the peak area (mAUs), and $C$ is the concentration of NIPAM $\left(\mathrm{mg} \mathrm{cm}^{-3}\right)$.

The dependence of the peak area on HPMet concentration was linear for concentration range of $1 \mathrm{mg}$ $\mathrm{cm}^{-3}$, for which the following equation applies:

$C=\frac{A-435.3}{10164.7}$

where $A$ is the peak area (mAUs), and $C$ is concentration of HPMet $\left(\mathrm{mg} \mathrm{cm}^{-3}\right)$. The amounts of residual monomers in synthesized copolymer hydrogels are given in Table 2.

The calculation regarding the quantity of monomer in the reaction mixture at the beginning of the reaction shows that the values were from 0.55 to $1.05 \%$ for NIPAM, and from 1.37 to $1.62 \%$ for HPMet. The content of residual monomers leads to the conclusion that the conversion of monomers was almost complete.

Table 2. Amount of residual monomers in xerogel

\begin{tabular}{lcccc}
\hline & \multicolumn{4}{c}{ EGDM content, mol\% } \\
\cline { 2 - 5 } $\mathrm{p}$ (NIPAM-co-HPMet) & 1 & \multicolumn{4}{c}{1.5} & 2 & 3 \\
\cline { 2 - 5 } & \multicolumn{5}{c}{ Residual monomer, $\mathrm{mg} \mathrm{g}^{-1}$} \\
\hline NIPAM & 8.006 & 8.109 & 9.675 & 5.076 \\
HPMet & 1.079 & 1.088 & 1.273 & 1.056 \\
\hline
\end{tabular}

\section{Swelling behavior}

The time dependence of hydrogels swelling ratio, $\alpha$, for $p$ (NIPAM-co-HPMet) observed at temperatures of $10^{\circ} \mathrm{C}$ is given in Figure 5 . As it can be seen, the swelling ratio increases extensively during the first $6 \mathrm{~h}$.

At the temperature of $10{ }^{\circ} \mathrm{C}$ the swelling ratio is about $20 \%$ higher compared to the values obtained for swelling ratio at $20{ }^{\circ} \mathrm{C}$ [32]. The highest swelling ratio was noted in the hydrogel with the lowest EGDM cross-

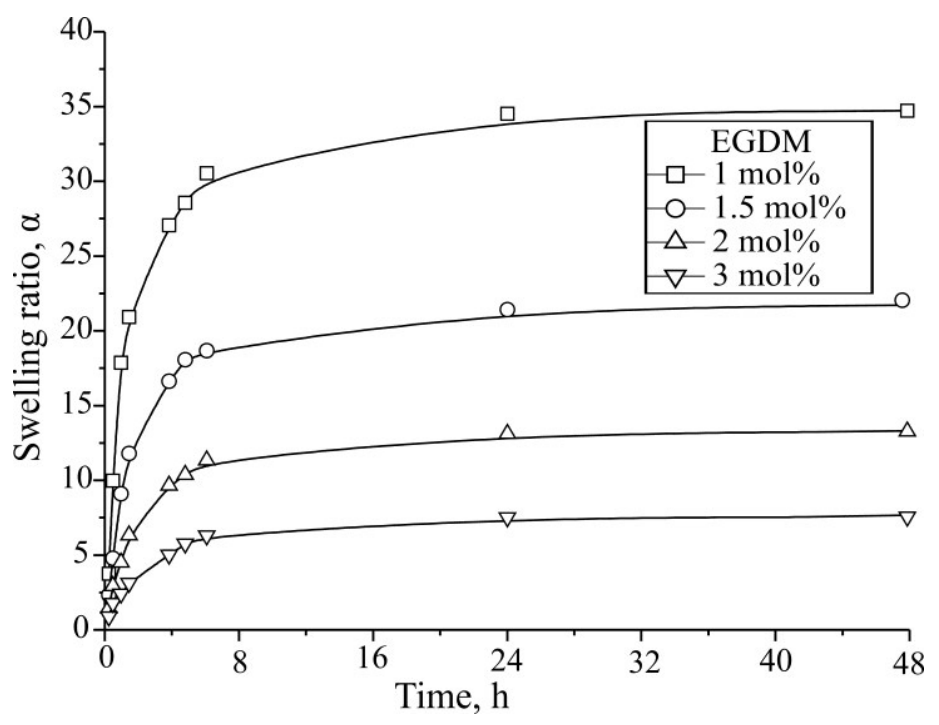

Figure 5. Swelling ratio, $\alpha$, at $10^{\circ} \mathrm{C}$ for $p$ (NIPAM-co-HPMet) hydrogels with different EGDM content. 
linker content at $10{ }^{\circ} \mathrm{C}$, i.e., $1 \mathrm{~g}$ of gel with $1 \mathrm{~mol} \%$ EGDM can absorb about $35 \mathrm{~g}$ of water. The swelling ratio decreases at both temperatures with the increase of the cross-linking degree, as expected, because the higher cross-linker content increases the density of cross-linking, thus reducing the mobility of polymer chains. The reason for the reduction of the swelling ratio at all temperatures when the amount of crosslinker is increased is the formation of a thicker crosslinking in the polymer gel. Then, the polymer chains have less space to expand, they are more fixed and, as a consequence the water absorption is lower. By adjusting the cross-linker content, the internal free volume that can be filled with water molecules can be changed. On the contrary, when the amount of crosslinker is lower, the length of polymer chains between two nodes is greater and the chains can expand and absorb more water. Great internal free volume allows a greater amount of water to be placed inside the gel, which favors the swelling [32].

The water transport into p(NIPAM-co-HPMet) polymer networks may be analyzed based on the nature of the sorption kinetics of the initial swelling data fitted to the exponential Ficks equation, only valid for the first $60 \%$ of the fractional uptake:

$$
F=M_{t} / M_{\mathrm{e}}=k t^{n}
$$

where $F$ is the fractional sorption, $M_{\mathrm{t}} / M_{\mathrm{e}} ; M_{\mathrm{t}}$ and $M_{\mathrm{e}}$ are the amounts of he absorbed solvent at time $t$ and equilibrium, respectively; $k$ is a kinetic constant incurporating characteristic of the network structure, $n$ is the diffusion exponent which is indicative of the transport mechanism.

The logarithmic form of Eq. (4) was used to determine the values of $n$ and $k$, from slope and intercept the plots of In $F$ versus In $t$ for hydrogels at different EGDM contents:

$$
\ln F=\ln \left(M_{t} / M_{\mathrm{e}}\right)=\ln k+n \ln t
$$

If $n<0.5$ the swelling process is controlled by the Fickian diffusion mechanism, whereas a value of $0.5<n<$ $<1$ indicates an anomalous non-Fickian type diffusion and contributes to the water-sorption process. The calculated values for equilibrium swelling ratios and for the linear dependence of $\ln \left(M_{t} / M_{\mathrm{e}}\right)$ on $\ln t$ of $\mathrm{p}$ (NIPAM-Co-HPMet) hydrogels for hydrogel samples with different compositions at 20 and $40{ }^{\circ} \mathrm{C}$ are shown in Table 3.

The obtained values for diffusion exponents, $n$, at the temperature of $20{ }^{\circ} \mathrm{C}$ increases from 0.602 to 0.793, so $p$ (NIPAM-Co-HPMet) is classified as a hydrogel with anomalous transport behavior, which is intermediate between Fickian and Case II $(n=1)$, also known as non-Fickian behavior. Their swelling process is controlled by the diffusion of liquids and the relaxation of the polymer chains. Different calculated diffusion exponents for the swelling at $40{ }^{\circ} \mathrm{C}$ ( $n$ is between 0.303 and 0.311 ) suggests that the swelling process is controlled by diffusion only. This indicates that the p(NIPAM-co-HPMet) hydrogels are submitted to the Fickian diffusion for all EGDM molar ratio. This evidence also shows that the swelling transport mechanism was transferred from Fickian to non-Fickian transport with the decreasing themperature. The results in Table 3 indicate that as the EGDM content increases, the water fractional uptake at the same absorption time decreases, but the kinetic constant, $k$, and diffusion exponents, $n$, increase. The kinetic constants are higher at $40{ }^{\circ} \mathrm{C}$ and this fact suggests that the diffusion rate decreases at the temperature upper LCST, due to the decrease in size of free spaces in the network.

Comparing the obtained swelling results with the $\mathrm{p}$ (NIPAM-co-HPMet) hydrogels swelling ratio results obtained by gamma irradiation and described in the published work of Nizam El-Din, certain differences in the swelling ratio are noted [29]. The gels obtained by gamma irradiation have a lower swelling ratio compared to the gels obtained by radical copolymerization in the presence of EGDM cross-linker. By using gamma irradiation, the cross-linking intensity of copolymer depended on the intensity of gamma rays, and p(NIPAM-co-HPMet) hydrogel with lower molar ratio of HPMet ( 2 mol\%), obtained by using $20 \mathrm{kGy}$ gamma rays at $25 \stackrel{\circ}{ } \mathrm{C}$ in water had a swelling ratio of about 6 . Similar result were obtained for $\mathrm{p}$ (NIPAM-co-HPMet) hydrogel with a higher molar ratio of HPMet monomer (10 mol\%) produced by the polymerization method of Wensheng Cai and collaborators [14], which also achieved the swelling ratio of 6 .

The thermosensitive nature of $p$ (NIPAM-co-HPMet) was investigated by monitoring volume changes of swollen hydrogels with the increase of temperature.

\begin{tabular}{|c|c|c|c|c|c|c|c|c|}
\hline \multirow[t]{2}{*}{ EGDM, mol\% } & \multicolumn{4}{|c|}{$20^{\circ} \mathrm{C}$} & \multicolumn{4}{|c|}{$40{ }^{\circ} \mathrm{C}$} \\
\hline & $\alpha$ & $n$ & $k \times 10^{2} / \mathrm{min}^{-1 / 2}$ & $R^{2}$ & $\alpha$ & $n$ & $k \times 10^{2} / \mathrm{min}^{-1 / 2}$ & $R^{2}$ \\
\hline 1 & 29.589 & 0.793 & 0.959 & 0.973 & 5.79 & 0.303 & 1.705 & 0.913 \\
\hline 1.5 & 18.002 & 0.751 & 1.230 & 0.953 & 4.29 & 0.304 & 1.708 & 0.913 \\
\hline 2 & 11.043 & 0.669 & 1.825 & 0.962 & 2.36 & 0.306 & 1.709 & 0.913 \\
\hline 3 & 6.244 & 0.602 & 3.016 & 0.984 & 1.60 & 0.311 & 1.749 & 0.957 \\
\hline
\end{tabular}

Table 3. Equilibrium swelling ratio, $\alpha$, and kinetic parameters of water diffusion into $p$ (NIPAM-Co-HPMet) hydrogels 
The swelling ratios as dependent on the temperature and EGDM cross-linker content are shown in Figure 6a and $b$, respectively.

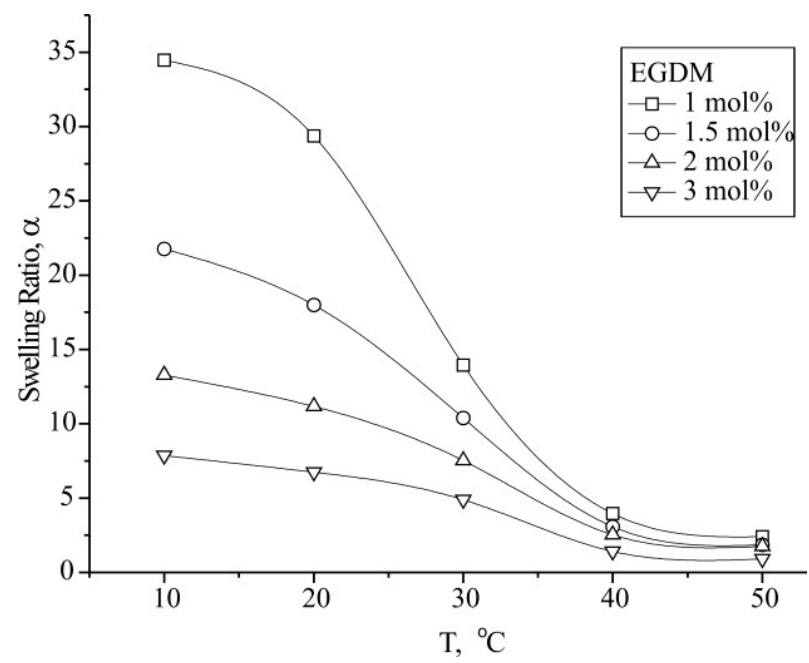

(a)

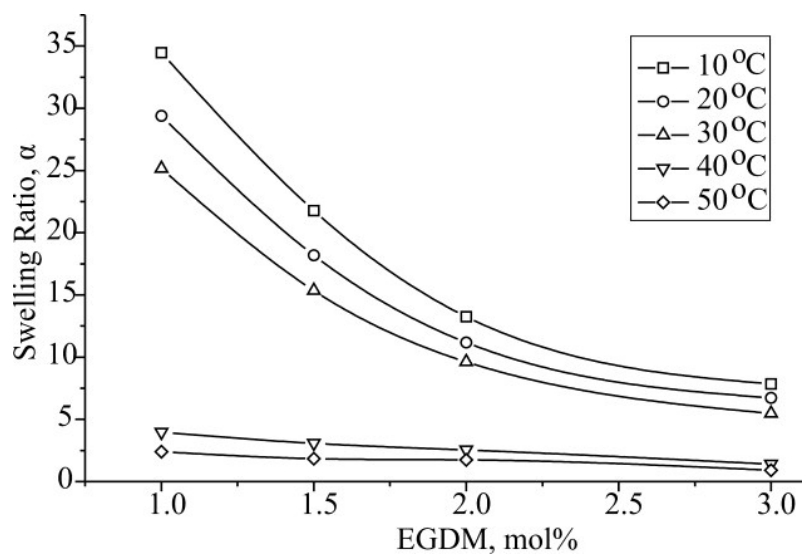

(b)

Figure 6. Swelling ratio, $\alpha$, of $p$ (NIPAM-co-HPMet) hydrogels in dependents on: a) temperature and b) EGDM content.

The decrease of the swelling ratio with the temperature increase is noted as an important characteristic of $p$ (NIPAM-co-HPMet). As it can be seen, the highest swelling ratio values of the hydrogel were reached at the temperatures of 10 and $20{ }^{\circ} \mathrm{C}$ began to decrease, passing through the phase transition and intensive decrease at $40{ }^{\circ} \mathrm{C}$, and above $50{ }^{\circ} \mathrm{C}$ reach asymptotic values ( $\alpha=0.7$ for hydrogel with $3 \mathrm{~mol} \%$ EGDM at 50 ${ }^{\circ} \mathrm{C}$ ). Phase transition can be noted at temperature range $30-40{ }^{\circ} \mathrm{C}$. These results are consistent with published literature data [29]. The LCST of $p$ (NIPAM-co-HPMet) hydrogels was determined at $34{ }^{\circ} \mathrm{C}$ using DSC [14]. The pure pNIPAM hydrogel has LCST at $32{ }^{\circ} \mathrm{C}$ [6]. By copolymerization of NIPAM with hydrophilic HPMet monomer, it was achieved that LCST of p(NIPAM-co-HPMet) copolymer had slightly higher LCST than PNIPAM hydrogel and became closer to the physiological tem- perature. Visual monitoring of hydrogels at the phase transition temperature shows that they become opaque, milky white in color, and their collapse occurs, i.e. the contraction. The phase transition of hydrogel is determined by a delicate balance between the hydrophilic and hydrophobic groups inside the hydrogels. Because of the presence of hydrophilic HPMet monomer, the influence of hydrophobic NIPAM monomer groups is reduced and LCST of $p$ (NIPAM-Co-HPMet) copolymer is increased compared to pure pNIPAM. During the phase transition the breaking of hydrogen bonds and water molecules between polymer chains and the domination of hydrophobic interactions between polymer chains occur, which causes the elimination of water molecules from hydrogel. As it was published earlier, the number of hydrogen bonds in the hydrogel increases the collapse of the gel. They can further be built from the terminal $\mathrm{OH}$ group of HPMet with electronegative $\mathrm{O}$ atom from the ester functional groups (HPMet and EGDM), or with $\mathrm{N}$ from NIPAM [32].

All noted characteristics of $p$ (NIPAM-co-HPMet) hydrogel are very important for their potential application as a carrier for the controlled release of NSAID. For the intelligent delivery of antipyretics responding to the raised body temperature in a state, a thermosensitive release system is required. This is the reason for further studying of p(NIPAM-co-HPMet) as an "intelligent gel", a material that reacts to the stimulus of the temperature change.

\section{Loading and release of ibuprofen studies}

The investigation of the content and amount of the released ibuprofen from thermosensitive hydrogels depending of temperature was carried out by HPLC. A calibration curve was drawn using a characteristic intensive peak with maximum absorption wavelength $\left(\lambda_{\max }\right)$ at $225 \mathrm{~nm}$ from DAD detector and the HPLC chromatogram $\left(R_{\mathrm{t}}=2.97 \mathrm{~min}\right)$ for ibuprofen. The dependence of the peak area on the ibuprofen amount is linear for the concentration range to $1 \mathrm{mg} \mathrm{cm}^{-3}$. For linear dependence, the following equation applies:

$C=\frac{A-201.2}{34952.1}$

where $A$ is the peak area (mAUs), and $C$ is the the amount of ibuprofen $\left(\mathrm{mg} \mathrm{cm}^{-3}\right)$. From this equation the unknown released concentration from the samples was calculated. The amount of ibuprofen loaded in the hydrogels was measured before the release experiment. The loading process was carried out in the saturated solution of ibuprofen and the amounts measured for hydrogels with different cross-linker ratio are shown in Table 4.

It was found that the amount of loaded ibuprofen depended on the hydrogel composition, according to 
their swelling properties described in the previous part. The results for the released ibuprofen from hydrogels at room temperatures of 20 and $40{ }^{\circ} \mathrm{C}$, similar to the body fever temperature, are shown in Figure $7 \mathrm{a}$ and $7 b$, respectively.

Table 4. The amount of loaded ibuprofen into p(NIPAM-co-HPMet)

\begin{tabular}{lcc}
\hline \multirow{2}{*}{ EGDM, mol\% } & \multicolumn{2}{c}{ Loaded ibuprofen } \\
\cline { 2 - 3 } & $\mathrm{mg} / \mathrm{g}_{\text {xerogel }}$ & $\%$ \\
\hline 1 & 481.77 & 97.32 \\
1.5 & 396.35 & 84.74 \\
2 & 337.49 & 61.29 \\
3 & 241.79 & 51.36 \\
\hline
\end{tabular}

The analysis of the obtained results in the first $24 \mathrm{~h}$ shows that higher ibuprofen concentration release from hydrogel is achieved when the system is exposed to higher temperature. It can be observed that at $40{ }^{\circ} \mathrm{C}$ the hydrogel with the lowest cross-linker content released the largest amount of ibuprofen (64.21 $\mathrm{mg} / \mathrm{g}_{\text {xerogel, }}$ or $13.33 \%$ of the total loaded mass). Therefore, different temperatures may be responsible for different release behaviors. Namely, at room temperature, when the hydrogel containing ibuprofen is immersed into the water medium, the drug is transferred from the gel into water by free diffusion. If the temperature is increased, besides the free diffusion, there is an active drug extrusion of incorporated ibuprofen due to the collapse of swollen hydrogel as a consequence of the temperature increase and phase transition occurrence. This higher release rate may be related to the higher swelling ratio of the hydrogel and the weak $\mathrm{H}$-bonding interaction between ibuprofen and the polymer network. At the temperature higher

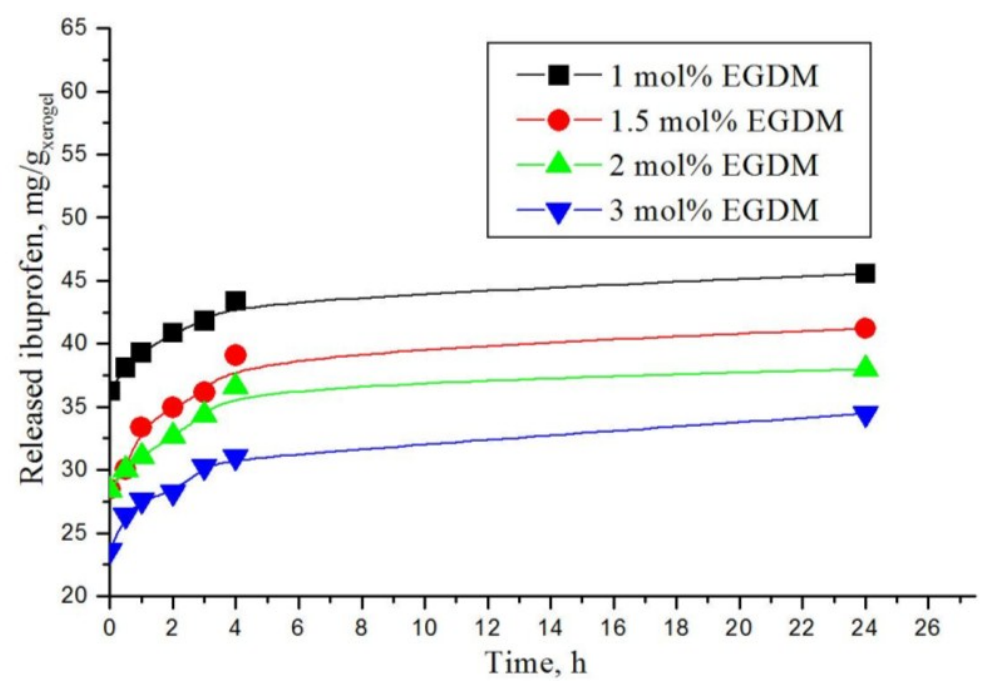

(a)

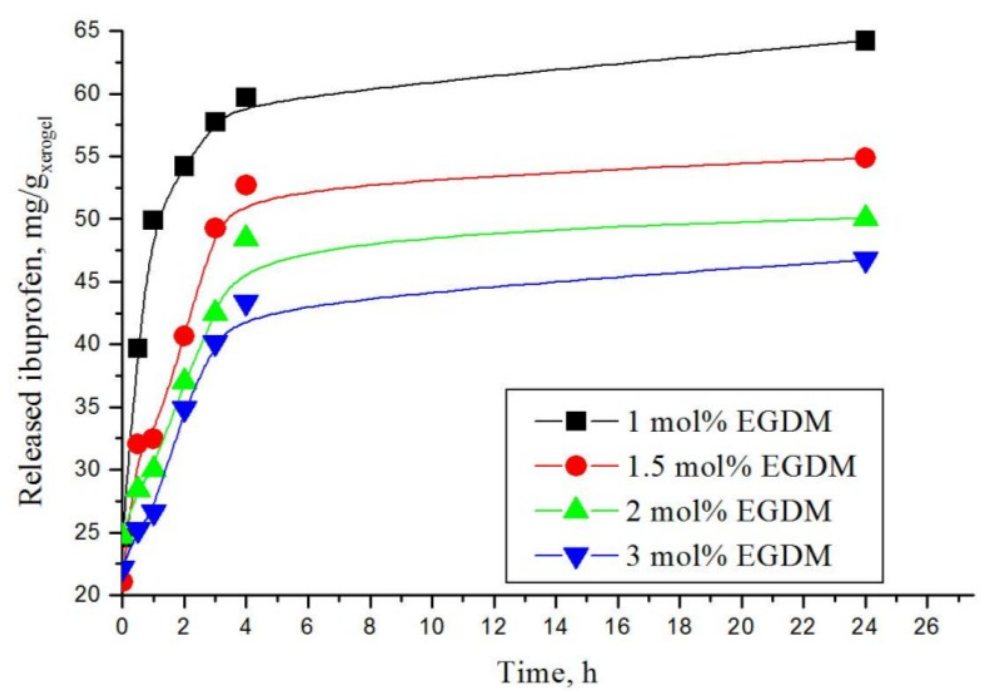

(b)

Figure 7. Ibuprofen release from $p$ (NIPAM-co-HPMet) hydrogels at: a) 20 and b) $40{ }^{\circ} \mathrm{C}$. 
than LCST, the intermolecular hydrogen bonding between ibuprofen and hydrogel chains was broken and the drug releases from the hydrogel. The phase transition occurrence is leads to p(NIPAM-co-HPMet) hydrogel deswell with the increase of temperature, which leads to the decrease of the swelling degree. Thus the results are consistent with the achieved equilibrium swelling degrees of synthesized hydrogels. The kinetic parameters of the ibuprofen release mechanism from hydrogel were assessed by fitting experimental release data to Fick's equation (5) and presented in Table 5.

Table 5. Kinetic parameters of released ibuprofen from $p$ (NIPAM-Co-HPMet) at 20 and $40{ }^{\circ} \mathrm{C}$

\begin{tabular}{lccccc}
\hline & \multicolumn{4}{c}{ Released ibuprofen } \\
\cline { 2 - 3 } & \multicolumn{2}{c}{$20^{\circ} \mathrm{C}$} & & \multicolumn{2}{c}{$40^{\circ} \mathrm{C}$} \\
\cline { 2 - 5 } \cline { 4 - 6 } & $n$ & $\begin{array}{c}k \times 10^{2} \\
\mathrm{~min}^{-1 / 2}\end{array}$ & $n$ & $\begin{array}{c}k \times 10^{2} \\
\mathrm{~min}^{-1 / 2}\end{array}$ \\
\hline 1 & 0.099 & 0.959 & & 0.362 & 1.705 \\
1.5 & 0.073 & 1.230 & & 0.233 & 1.708 \\
2 & 0.068 & 1.825 & & 0.225 & 1.709 \\
3 & 0.052 & 3.016 & 0.194 & 1.749 \\
\hline
\end{tabular}

The obtained results indicate that the release process is controlled by the Fickian diffusion mechanism ( $n$ $<0.5$ ) at both temperatures. The release profiles showed a reduction in the released amount of ibuprofen at both temperatures as the EGDM concentration was increased owing to the higher network density and small available free volume between the chains. On the other hand, as the EGDM content decreased, more ibuprofen was released from the hydrogel, which could be explained by the swelling behavior of hydrogels, as a function of EGDM content.

One of the most attractive features of these hydrogels as drug carriers is their intelligent property to external temperature changes. It is important and practical to examine the drug release data from those hydrogels at the temperature higher than LCST like the fever body temperature $\left(40{ }^{\circ} \mathrm{C}\right)$. A potential application of $p$ (NIPAM-co-HPMet) hydrogel in the drug delivery systems modified by temperature can be expected.

\section{CONCLUSIONS}

A new method of the preparation of thermosensitive hydrogels based on NIPAM with $5 \mathrm{~mol} \%$ of HPMet monomer, using various concentrations of cross-linker was described. When analyzing the FTIR spectra of the obtained p(NIPAM-co-HPMet) hydrogels containing different amounts of EGDM cross-linker, no significant difference in the structure was observed. SEM microscopy confirmed the porous structure of hydrogels and the changed structure with incorporated ibuprofen. Three-glass transition temperatures were determined by the DSC method. The content of residual monomers showed that the conversion of NIPAM and HPMet monomers was almost complete. The swelling ratio of hydrogels decreased at all temperatures with the increase of cross-linker content, and also with the increase of the temperature. The swelling transport mechanism was transferred from Fickian at $40{ }^{\circ} \mathrm{C}$ to non-Fickian transport with the decreasing temperature at $20{ }^{\circ} \mathrm{C}$. p(NIPAM-co-HPMet) are used as drug carriers for testing the ibuprofen modified release. The hydrogel with the highest swelling degree released the largest amount of ibuprofen at $40{ }^{\circ} \mathrm{C}$. This may be explained by the incorporation of more $\mathrm{OH}$ groups of ibuprofen that form hydrogen bonds in the polymer network. During the phase transition, they break because of the hydrogel collapse due to the increase of the temperature upper LCST. In fact, this gives an opportunity for a wider investigation of pharmaceutical application of these hydrogels, for the modified release of NSAID.

\section{Acknowledgement}

Financial support provided by the Ministry of Education, Science and Technological Development of the Republic of Serbia, for project No. TR-34012 is gratefully acknowledged.

\section{REFERENCES}

[1] N.A. Peppas, P. Bures, W. Leobandung, H. Ichikawa, Hydrogels in pharmaceutical formulations, Eur. J. Pharm. Biopharm. 50 (2000) 27-46.

[2] J.F. Mano, Stimuli-responsive polymeric systems for biomedical applications, Adv. Eng. Mater. 10 (2008) 515$-527$.

[3] Y. Qiu, K. Park, Environment-sensitive hydrogels for drug delivery, Adv. Drug Delivery Rev. 53 (2001) 321-339.

[4] H.W. Coover, N.H. Shearer, $N$-substitued acrylamides by vapor phase method using acrylic acid, US 2,719,177 (1955).

[5] M. Heskins, J. Guillet, Solution properties of poly( $N$-isopropylacrylamide), J. Macromol. Sci., A 2 (1968) 1441-1455 .

[6] Y.H. Bae, S.W. Kim, L.I. Valuev, Pulsatile drug delivery device using stimuli sensitive hydrogel, US 5,226,902 (1993).

[7] M.T. Garay, M.C. Llamas, E. Iglesias, Study of polymerpolymer complexes and blends of poly( $\mathrm{N}$-isopropylacrylamide) with poly(carboxylic acid): 1. Poly(acrylic acid) and poly(methacrylic acid), Polymer 38 (1997) 5091-5096.

[8] J.E. Chung, M. Yokoyama, M. Yamato, T. Aoyagi, Y. Sakurai, T. Okano, Thermo-responsive drug delivery from polymeric micelles constructed using block copolymers of poly( $\mathrm{N}$-isopropylacrylamide) and poly(butylmethacrylate), J. Controlled Release 62 (1999) 115-127. 
[9] Z. Shen, K. Terao, Y. Maki, T. Dobashi, G. Ma, T. Yamamoto, Synthesis and phase behavior of aqueous poly $(N$ isopropylacrylamide-co-acrylamide), poly( $N$-isopropylacrylamide-co- $N, N$-dimethylacrylamide) and poly( $N$-isopropylacrylamide-co-2-hydroxyethyl methacrylate), Colloid Polym. Sci. 284 (2006) 1001-1007.

[10] T. Gan, Y. Zhang, Y. Guan, In situ gelation of P(NIPAMHEMA) microgel dispersion and its applications as injectable $3 d$ cell scaffold, Biomacromolecules 10 (2009) 1410-1415.

[11] M. Kalagasidis-Krušić, S. J. Velicković, J. Filipović, Poly[(N-isopropylacrylamide)-co-(itaconic acid)] hydrogels with poly(ethylene glycol), Polym. Int. 59 (2010) 256-262 .

[12] C. Zhao, X. Zhuang, P. He, C. Xiao, C. He, J. Sun, X. Chen, $X$. Jin, Synthesis of biodegradable thermo- and $\mathrm{pH}-$-responsive hydrogels for controlled drug release, Polymer 50 (2009) 4308-4316.

[13] C.M. Schilli, M. Zhang, E. Rizzardo, S.H. Thang, Y.K. Chong, K. Edwards, G.A. Karlsson, H.E. Muller, A New Double-Responsive Block Copolymer Synthesized via RAFT Polymerization: Poly( $N$-isopropylacrylamide)block-poly(acrylic acid, Macromolecules 37 (2004) 7861-7866.

[14] W. Cai, E.C. Anderson, R.B. Gupta, Separation of lignin from aqueous mixtures by ionic and nonionic temperature-sensitive hydrogels, Ind. Eng. Chem. Res. 40 (2001) 2283-2288.

[15] M. Shibayama, S. Mizutani, S. Nomura, Thermal properties of copolymer gels containing $N$-isopropylacrylamide, Macromolecules 29 (1996) 2019-2024.

[16] M.D.C. Topp, P.J. Dijkstra, H. Talsma, J. Feijen, Thermosensitive micelle-forming block copolymers of poly(ethylene glycol) and poly( $N$-isopropylacrylamide), Macromolecules 30 (1997) 8518-8520.

[17] H. Inomata, S. Goto, S. Saito, Phase transition of $N$ substituted acrylamide gels, Macromolecules 23 (1990) 4887-4888.

[18] R.G. Sousa, W.M. Magalhães, R.F.S. Freitas, Glass transition and thermal stability of $\operatorname{poly}(N$-isopropylacrylamide) gels and some of their copolymers with acrylamide, Polym. Degrad. Stab. 61 (1998) 275-281.

[19] G. Grassi, R. Farra, P. Caliceti, G. Guarnieri, S. Salmaso, M. Carenza, M. Grassi, Temperature-Sensitive Hydrogels: Potential Therapeutic Applications, Am. J. Drug Delivery 3 (2005) 239-251.

[20] D.C. Coughlan, F.P. Quilty, O.I. Corrigan, Effect of drug physicochemical properties on swelling/deswelling kinetics and pulsatile drug release from thermoresponsive poly ( $N$-isopropylacrylamide) hydrogels, J Control. Release 98 (2004) 97-114.

[21] C. Elvira, J.F. Mano, J.S. Roman, R.L. Reis, Starch-based biodegradable hydrogels with potential biomedical applications as drug delivery systems, Biomaterials 23 (2002) 1955-1966.

[22] R. Yoshida, Y. Kaneko, K. Sakai, T. Okano, Y. Sakurai, Y.H. Bae, S.W. Kim, Positive thermosensitive pulsatile drug release using negative thermosensitive hydrogels, J. Controlled Release 32 (1994) 97-102.
[23] Y. Shin, J.H. Chang, J. Liu, R. Williford, Y.K. Shin, G.J. Exarhos, Hybrid nanogels for sustainable positive thermosensitive drug release, J. Controlled Release $\mathbf{7 3}$ (2001) 1-6.

[24] T. Okano, Y.H. Bae, H. Jakobs, S.W. Kim, Thermally onoff switching polymers for drug permeation and release, J. Controlled Release 11 (1990) 255-265.

[25] Y.Y. Akiyama, A. Kikuchi, M. Yamato, T. Okano, Ultrathin poly ( $\mathrm{N}$-isopropylacrylamide) grafted layer on polystyrene surfaces for cell adhesion/detachment control, Langmuir 20 (2004) 5506-5511.

[26] J. Kopeček, L. Šprincl, H. Bažilová, J. Vacík, Biological tolerance of poly( $N$-substituted acrylamides), J. Biomed. Mat. Res. 7 (1973) 111-121.

[27] T. Rustemeyer, S. De Ligter, B.M.E. Von Blomberg, P.J. Frosch, R.J. Scheper, Human T lymphocyte priming in vitro by haptenated autologous dendritic cells, Clin. Exp. Immunol. 117 (1999) 209-216.

[28] M. Save, J.V.M. Weaver. S.P. Armes, Atom transfer radical polymerization of hydroxy-functional methacrylates at ambient temperature: comparison of glycerol monomethacrylate with 2-hydroxypropyl methacrylate, Macromolecules 35 (2002) 1152-1159.

[29] H.M. Nizam El-Din, Characterization and caffeine release properties of $\mathrm{N}$-isopropylacrylamide/hydroxypropyl methacrylate copolymer hydrogel synthesized by gamma radiation, J. Appl. Polym. Sci. 119 (2011) 577$-585$.

[30] WHO Model List of essential Medicines, $17^{\text {th }}$ list, March 2011, World Health Organization.

[31] S.S. Adams, Discovery of Brufen, Chem. Brit. 23 (1987) 1193-1198.

[32] S.S. Ilić-Stojanović, Lj. Nikolić, V. Nikolić, M. Stanković, J. Stamenković, I. Mladenović-Ranisavljević, S.D. Petrović, Influence of monomer and crosslinker molar ratio on the swelling behaviour of thermosensitive hydrogels, Chem. Ind. Chem. Eng. Q. 18 (2012) 1-9.

[33] S.S. Ilić-Stojanović, Lj. Nikolić, V. Nikolić, J. Milić, J. Stamenković, G.M. Nikolić, S.D. Petrović, Potential application of thermosensitive hydrogels for controlled release of phenacetin, Hem. Ind. 66 (2012) 831-839.

[34] A. Allı, B. Hazer, Poly( $\mathrm{N}$-isopropylacrylamide) thermoresponsive cross-linked conjugates containing polymeric soybean oil and/or polypropylene glycol, Eur. Polym. J. 44 (2008) 1701-1713.

[35] M.Y. Mohan, K. Lee, T. Premkumar, K.E. Geckeler, Hydrogel networks as nanoreactors: A novel approach to silver nanoparticles for antibacterial applications, Polymer 48 (2007) 158-164.

[36] J. Brandrup, E. H. Immergut, Polymer Handbook, John Wiley, New York, 1975, p. III-147.

[37] J. Dai, S.H. Goh, S.Y. Lee, K.S. Slow, Complexation between poly(2-hydroxypropyl methacrylate) and three tertiary amide polymers, J. Appl. Polym. Sci. 53 (1994) 837-845. 


\section{IZVOD}

\section{SINTEZA I KARAKTERIZACIJA TERMOOSETLIVIH HIDROGELOVA I ISPITIVANJE MODIFIKOVANOG OSLOBAĐANJA IBUPROFENA}

Snežana S. llić-Stojanović ${ }^{1}$, Ljubiša B. Nikolić ${ }^{1}$, Vesna D. Nikolić ${ }^{1}$, Jela R. Milić ${ }^{2}$, Jakov Stamenković ${ }^{1}$, Goran M. Nikolić ${ }^{3}$, Slobodan D. Petrović ${ }^{4}$

${ }^{1}$ Univerzitet u Nišu, Tehnološki fakultet, Leskovac, Republika Srbija

${ }^{2}$ Univerzitet u Beogradu, Farmaceutski fakultet, Beograd, Republika Srbija

${ }^{3}$ Univerzitet u Nišu, Medicinski fakultet, Niš, Republika Srbija

${ }^{4}$ Univerzitet u Beogradu, Tehnološko-metalurški fakultet, Beograd, Republika Srbija

(Naučni rad)

Prikazan je metod sinteze hidrogelova poli( $N$-izopropilakrilamid-ko-2-hidroksipropilmetakrilata), p(NIPAM-ko-HPMet), sa 5 mol\% monomera HPMet-a dobijenih radikalnom polimerizacijom. Karakterizacija sintetisanih hidrogelova je izvedena određivanjem količine rezidualnih monomera i izvršena je njihova strukturna analiza pomoću infracrvene spektroskopije (FTIR), diferencijalne skenirajuće kalorimetrije (DSC) i skenirajuće elektronske mikroskopije (SEM). FTIR spektri sintetisanih hidrogelova $\mathrm{p}$ (NIPAM-ko-HPMet)-a sa različitim sadržajem umreživača EGDM-a pokazuju uzajamnu sličnost u strukturi. Površinska struktura liofilizovanih hidrogelova je porozna i uočavaju se čestice uklopljenog ibuprofena. Termička svojstva kserogelova $\mathrm{p}$ (NIPAM-ko-HPMet)-a pokazuju tri staklasta prelaza sa endotermnim pikovima slabog intenziteta. Sadržaj rezidualnih monomera dovodi do zaključka da je konverzija monomera tokom sinteze gotovo kompletna. Kinetika bubrenja hidrogelova pokazuje da se pri povećanju temperature od 20 na 40 ${ }^{\circ} \mathrm{C}$ mehanizam transporta tečnosti menja iz ne-Fikovog (proces bubrenja kontroliše difuzija tečnosti i relaksacija polimernih lanaca) u Fikov (kontrolisan samo difuzijom tečnosti). Mogućnost primene hidrogelova p(NIPAM-ko-HPMet)-a kao nosača lekova ispitivana je u zavisnosti od temperature. Ibuprofen, korišćen kao model lekovita supstanca, uklopljen je u hidrogel i količina oslobođene aktivne supstance određena je HPLC metodom. Utvrđeno je da uzorak hidrogela p(NIPAM-ko-HPMet)-a sa sadržajem umreživača od 1 mol\% EGDM-a dostiže najveći stepen bubrenja $(\alpha=34,72)$ na $10^{\circ} \mathrm{C}$ i otpušta najveću količinu ibuprofena na $40{ }^{\circ} \mathrm{C}\left(64,21 \mathrm{mg} / \mathrm{g}_{\mathrm{kserogel}}\right)$. Ispitana svojstva predstavljaju dobru osnovu za potencijalnu primenu hidrogelova kao nosača lekovitih supstanci sa modifikovanim oslobađanjem.

Ključne reči: $N$-Izopropilakrilamid • Kopolimerni hidrogel • Termičke osobine • Bubrenje •Ibuprofen 